the paintings were linked to patterns found on Turkish kilims today, but the Çatalhöyük patterns cannot be made into rugs using the weaving technology preserved at the site.

The book details much debate but few conclusions. The result is a good read that bespeaks the importance of this enigmatic and iconic site and highlights Balter's considerable journalistic skills. The book is both accessible and fascinating. Balter tries, with moderate success, to show us how personality, nationality and the training of the scientists involved influences their scientific ideas.

Yet the book left me distinctly dissatisfied: I learned more about the childhoods of the excavation team members than about ancient Çatalhöyük. This is an intelligent, provocative book by a distinguished science writer who visited the site every field season for six years, interviewed the excavators, and read their publications, which are referenced in extensive notes and a lengthy bibliography. The scholars who have worked at Çatalhöyük are impressive, the duration of excavations far in excess of normal expectations. Why then is so much about Çatalhöyük so unclear?

Perhaps the reason is Balter's adherence to a Hodder-like reluctance to settle on a single interpretation for a site that means so much to so many. What are we to think, then, of Çatalhöyük and its evidence, excavators, myths? That remains the post-processual question. Pat Shipman is in the Department of

Anthropology, Pennsylvania State University, 315 Carpenter Building, University Park,

Pennsylvania 16802, USA.

\section{Hidden depths}

Fathoming the Ocean: The Discovery and
Exploration of the Deep Sea
by Helen M. Rozwadowski
Belknap: 2005.304 pp. $\$ 25.95, £ 16.95$,
$€ 24$

The Remarkable Life of William Beebe:

Explorer and Naturalist

by Carol Grant Gould

Shearwater: 2004.416 pp. $\$ 30$

Descent: The Heroic Discovery of the

Abyss

by Brad Matsen

Pantheon: 2005. 286 pp. \$25

\section{Jon Copley}

Deep-sea science is big science. Ocean covers 365 million square kilometres, and most of it is more than two kilometres deep. To understand what goes on down there, you need a ship to brave the high seas and equipment that can reach into the abyss. As today's researchers agonize over grant proposals and publication records, some may yearn for the time when they could chart the depths without worrying about tenure or research assessment exercises.

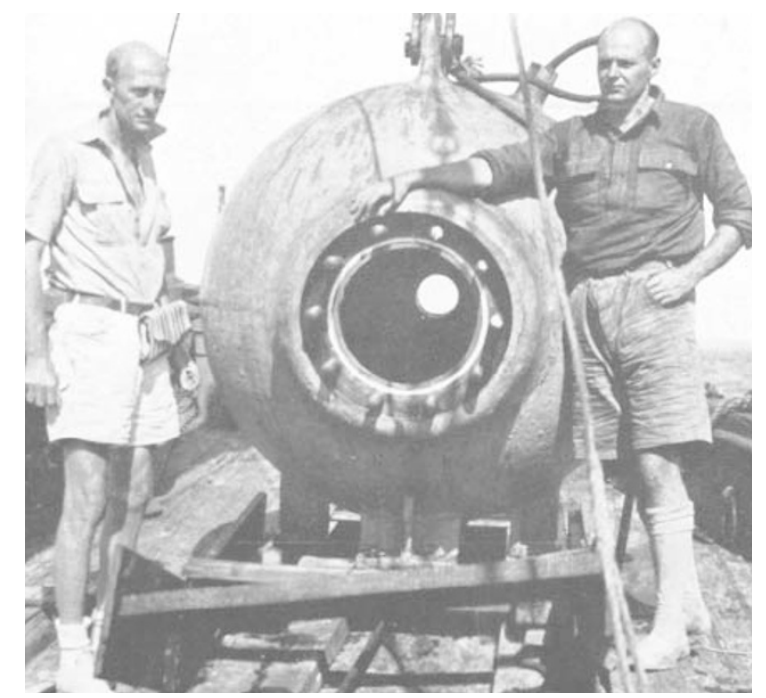

The descent of man: William Beebe (left) and Otis Barton used their bathysphere to explore the ocean depths.

But as these three books charting the history of deep-sea science reveal, that golden age never existed.

Fathoming the Ocean by Helen Rozwadowski chronicles the birth of deep-sea oceanography, from early observations by Benjamin Franklin to the voyage of HMS Challenger in the 1870s. She weaves a rich narrative from the work of renowned as well as lesser-known oceanographers. While unearthing the foundations of the subject, she reveals some striking parallels with modern research careers.

Like today, there was plenty of job-hopping, with worries about money and research output. When Edward Forbes accepted a chair in botany at King's College, London, in 1843, he also became curator of the museum at the Geological Society of London to boost his income. But he was concerned that he no longer had any time for research, and jumped ship just a year later for a job with the Geological Survey. This strategic jockeying paid off, and he was later appointed regius chair in natural history at the University of Edinburgh.

Then there is the tale of George Wallich, who sailed as a naturalist on the cable-surveying voyage of HMS Bulldog. Wallich hoped the expedition would make his name in scientific circles, as other voyages of discovery had done for T. H. Huxley and Darwin. But it was not to be. Despite initial enthusiasm about his results, Wallich failed to secure election to the Royal Society. Under the financial pressures of supporting his wife and children, he became a photographer instead. He described the prospects of his new career as "more than I could venture to hope for in that muddy sea of science". His story may sound familiar to today's postdocs-turned-plumbers.

Worrying about funding also occupied the mind of deep-sea pioneer William Beebe. To write The Remarkable Life of William Beebe, Carol Gould was granted unprecedented access to Beebe's personal papers that he had bequeathed to his colleague Jocelyn Crane.
Grant's detailed and well organized biography is a treasure. From the waters of Bermuda to the jungles of Venezuela, Beebe was tireless in his enthusiasm for understanding the living world, and he provided the inspiration for many scientific careers.

Brad Matsen's Descent focuses on Beebe's collaboration with Otis Barton and their bathysphere dives. In the 1930s, they plunged six times deeper than anyone before and became the first people to see deep-sea life in situ. "No human eye had glimpsed this part of the planet before us," wrote Barton, often considered the more prosaic of the pair, "this pitchblack country lighted only by the pale gleam of an occasional spiralling shrimp." Matsen offers a worthy tribute to their remarkable achievement, and explores the tensions between them. His account is captivating, although not as lavishly referenced as Gould's biography.

In the days before research councils and national science foundations, Beebe was using publicity and popular accounts of his work to charm funds from philanthropists. Like some who popularize their research today, he sometimes encountered snobbery from his academic peers. But deep-sea research has always been newsworthy and captured the public imagination. On 26 April 1857, the front page of The New York Herald hailed the laying of the first transatlantic cable as the "great work of the age", and illustrated the story with microscope drawings of seafloor sediments. Seventy-eight years later, radio listeners right across the United States and Western Europe tuned in to hear Beebe's voice live from the bathysphere at a depth of

\section{NATURE EDITOR WINS AVENTIS BOOK PRIZE}

Philip Ball, a science writer and consultant editor of Nature, has won this year's Aventis Prizes for Science Books General Prize. Critical Mass: How One Thing Leads to Another (William Heinemann) takes a look at the application of physics to the collective behaviour of society. Bill Bryson, who chaired this year's judging panel and won the prize in 2004, says: "This is a wide-ranging and dazzlingly informed book about the science of interactions. I can promise you'll be amazed." (For a review of this book see Nature $\mathbf{4 2 8 ,}$

\section{7-368; 2004.)}

Robert Winston takes the junior Aventis Prize for his children's book What Makes Me, Me? (Dorling Kindersley). The judging panel for this prize included schoolchildren as well as adult writers and scientists.

The winners received their awards at a ceremony on 12 May 2005 at the Royal Society in London. 
670 metres. Beebe vividly described his visit to another world, three decades before the televised Moon landings.

Most modern grant proposals require applicants to describe the wider benefits of their work to society. Those studying the deep sea can point to examples of medical treatments, industrial enzymes and even tips for making better optical fibres based on the glass skeletons of deep-sea sponges. Rozwadowski describes how early workers highlighted the benefits of seafloor dredging for cable surveys when lobbying for the use of HMS Lightning, HMS Porcupine and HMS Challenger. But Gould and Matsen show that Beebe got funding by promising a payback in the joy of knowledge itself. At the age of 16, he wrote that "to be a Naturalist is better than to be a King". Taken together, these books reveal how far we have come in understanding the largest habitat on our planet - and how much further we have to go.

Jon Copley is at the National Oceanography Centre, Southampton SO14 3ZH, UK.

\section{The music of life}

\section{Composer Thilo Krigar seeks to represent the flow of genetic information.}

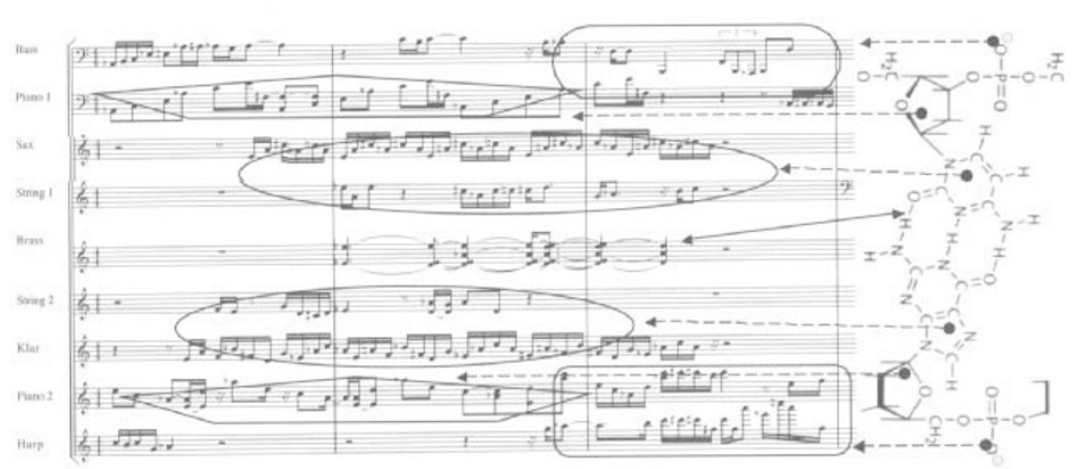

Juliane Mössinger

Music and science seem irreconcilable to many, but there is a close and long-standing relationship between them. Since antiquity, music has been categorized as scientia mathematica, together with arithmetic, geometry and astronomy. In the eighteenth century, Johann Sebastian Bach composed some almost mathematically constructed canons as part of his Musical Offering. And Karlheinz Stockhausen used the Fibonacci series to determine the durations of the 33 Moments in Mikrophonie I/ in 1965. More recently, the sciences have offered patterns in data, such as those arising from genomics, as inspirations for musical composition.

But previous attempts to portray DNA, the icon of twentieth-century science, in musical terms have been limited to the computerized conversion of nucleotide sequences into audible patterns. The composer Thilo Krigar, however, is not interested in simply representing the structure or sequence of the DNA molecule itself, but in a musical exploration of the flow of genetic information. He is fascinated by the idea that the dynamic and continuous renewal of our cells relies on the information coded in our DNA. He perceives this process of 're-creation' as the ultimate form of creativity - a metaphor for composition.

The Berlin-based cellist and composer has been working on DNA in Concert for the past five years, using the atoms that compose the DNA molecule as a starting point. He converts the number of outer valence or total electrons of hydrogen, carbon, nitrogen, oxygen and phosphorus into an equivalent number of semitone steps. These then form five different musical intervals, which, in turn, are the basis for the melodic and harmonic structure of the composition. Krigar then uses other musical tools to represent the biochemistry of the cell. Stability in the harmonic architecture of the music, expressed by a double octave, for example, represents the chemical stability of hydrogen bonding. Although Krigar is interested in a close musical portrayal of biochemical processes, he realizes that a representation of all of the atoms, molecules and chemical bonds is virtually impossible and, musically, may not be desirable. Above all, he wants the resulting music to be aesthetically appealing and demanding.

DNA in Concert begins with a prelude that depicts the archaic process of reverse transcription - the mechanism thought to be involved in the transition from RNA into DNA on the early Earth. The main body of the work, 'Seasons4life', is then divided into four parts: Transcription, Translation, Metabolism and Replication.

During Transcription, the music reflects the physical tension in the DNA caused when RNA polymerase, the enzyme that copies DNA into RNA, unwinds and rewinds the template DNA helix. Saxophones represent the three-dimensional structure of the double helix, and the strings the actual generation of RNA molecules.

The music of Translation is focused on the activity of the ribosomes, complex biochemical machines that catalyse the translation of a nucleic-acid message into a protein sequence. Interjections of percussion, for example, represent amino acids as a building material. Live electronic sound embodies the energy consumed during protein assembly.

In Metabolism, the chemical signals that connect the activities of the cellular proteins are transformed into musical signals that are passed on from one musician to another. Different groups of instruments compete with one another through intensifying motifs to illustrate the polymerization of the two DNA daughter strands during replication.

Newly developed harmonies then portray the processes involved in cell division in the concluding passage, Proliferation, before the music retreats back to the structure of DNA.

The music is modern but not atonal. It is reminiscent of minimalism but has elements that resemble the dramatic romanticism of a Mahler symphony. The piece is written for a chamber ensemble, and the musicians are expected to move around the room, giving the audience the feeling of being surrounded by the double helix and the biochemical processes in the cell. Loudspeakers projecting computer-generated sound add to the surround effect. Digital movies of cellular processes bring a visual component to the performance.

The composition is not limited to repeating sequential tones, nor does it simply attempt a one-to-one representation of the molecular reality in the cell. The composer's work is based instead on biological concepts, stressing the parallels between biological processes and human creativity. He wants to give the listener a musical experience of the biochemistry in the cell and to become progressively aware of the life process taking place within ourselves. DNA in Concert is a work in progress. Its world premiere - minus an unfinished coda - will be performed by the Pythagoras Strings on 28 and 29 May 2005 at TESLA im Podewils'schen Palais in Berlin, Germany. Juliane Mössinger is an associate editor in the physical sciences at Nature.

" www.dna-in-concert.de 